\title{
ANALISA PERUBAHAN TURBIDITAS PADA LIMBAH CAIR INDUSTRI TAHU MENGGUNAKAN KITOSAN DARI LIMBAH SISIK IKAN BANDENG
}

\section{ANALYSIS OF TURBIDITY CHANGE IN TOFU INDUSTRY LIQUID WASTE USING CHITOSAN FROM MILKFISH SCALES WASTE}

\author{
Stephanie Bija ${ }^{1 *}$, Yulma $^{1}, \operatorname{Imra}^{1}$, Aldian $^{2}$, Akbar $^{2}$ \\ ${ }^{1}$ Dosen di Program Studi Teknologi Hasil Perikanan dan Manajemen Sumberdaya Perairan, Fakultas \\ Perikanan dan IImu Kelautan, Universitas Borneo Tarakan, Amal Lama 77115 Kalimantan Utara \\ ${ }^{2}$ Mahasiswa di Program Studi Teknologi Hasil Perikanan, Fakultas Perikanan dan IImu Kelautan, \\ Universitas Borneo Tarakan, Amal Lama 77115 Kalimantan Utara \\ email : bijastephanie92@gmail.com
}

\begin{abstract}
ABSTRAK
Biokoagulan merupakan koagulan alami yang bersifat ramah lingkungan. Koagulan alami yang digunakan berasal dari kitosan dan berperan dalam mengikat kotoran yang terkandung dalam air. Penelitian ini bertujuan untuk menganalisis perubahan turbiditas pada limbah cair industri tahu dengan pemberian kitosan dari limbah sisik ikan bandeng. Konsentrasi kitosan yang digunakan untuk mengukur turbiditas limbah cair tahu yaitu 10 ppm, 20 ppm, dan 30 ppm. Hasil penelitian menunjukkan bahwa penggunaan kitosan yang dihasilkan dari limbah sisik ikan bandeng memberikan perubahan turbiditas dengan nilai yang menurun kemudian naik dan menurun lagi. Penggunaan biokoagulan berbasis kitosan dengan konsentrasi tinggi dapat menurunkan nilai turbiditas. Secara berturut-turut diperoleh nilai turbiditas 353,07 NTU, 201 NTU, dan 29,27 NTU.
\end{abstract}

Kata kunci : Kekeruhan; Koagulan; Limbah Cair; Sisik Ikan

\section{ABSTRACT}

Bio coagulant is a natural coagulant that is environmentally friendly. The natural coagulant used was from chitosan and has a role in binding impurities contained in water. This study aims to analyze changes in turbidity in tofu industry liquid waste by providing chitosan from milkfish scales waste. Chitosan concentration used to measure turbidity of tofu wastewater were 10 ppm, $20 \mathrm{ppm}$, and $30 \mathrm{ppm}$. The results showed that the use of chitosan produced from milkfish scales waste gave a change in turbidity with decreasing value then increasing and decreasing again. the use of bio coagulant from chitosan with high concentration can decrease the turbidity value. The turbidity values were 353.07 NTU, 201 NTU, and 29,27 NTU, respectively.

Keywords : Coagulant; Fish Scales; Liquid Waste; Turbidity

\section{PENDAHULUAN}

Tahu adalah makanan tradisional berbahan dasar kacang kedelai yang mudah ditemukan karena keberadaannya sangat digemari oleh masyarakat. Industri tahu saat ini telah banyak tersebar diseluruh kota Indonesia. Pada proses pembuatannya, tahu memerlukan banyak air untuk tahap sortasi, perendaman, pengupasan kulit, pencucian, 
penggilingan, perebusan, dan penyaringan (Levina, 2016). Besarnya pemakaian air pada proses pembuatan tahu ini mengakibatkan volume limbah cair yang dihasilkan besar dan berdampak terhadap lingkungan karena limbahnya langsung dibuang ke badan sungai tanpa melalui pengolahan terlebih dahulu. Dampak yang ditimbulkan seperti kekeruhan dan bau yang dtimbulkan karena kandungan protein pada limbahnya mengalami pembusukan.

Kekeruhan merupakan suatu kondisi air yang mengandung partikel-partikel terdispersi. Partikel-Partikel terdispersi ini dapat berasal dari bahan organik maupun anorganik, seperti lumpur maupun limbah hasil industri (Hendrawati et al., 2015). Adanya kekeruhan mengakibatkan sinar matahari sulit masuk ke dalam perairan sehingga dapat membahayakan organisme yang hidup di dalamnya. Kekeruhan dapat dikurangi dengan cara mengendapkan partikel-partikel penyebabnya. Pengendapan ini dapat dilakukan dengan penambahan biokoagulan. Biokoagulan merupakan koagulan alami yang aman dan ramah lingkungan. Salah satu sumber biokoagulan adalah kitosan.

Kitosan merupakan senyawa berbentuk padatan amorf yang memiliki warna putih hingga kecokelatan dan bersifat polielektrolit. Adanya sifat polielektrolit inilah yang menyebabkan kitosan berpotensi sebagai koagulan alami yang biodegradable (Wardhani et al. 2014). Koagulan ini akan mengikat partikel atau kotoran yang terkandung di dalam air, lalu menjadikan partikel-partikel tersebut menjadi gumpalan berukuran besar sehingga mudah mengendap (Suharto, 2011). Sumber kitosan, salah satunya berasal dari sisik ikan yang umumnya merupakan limbah dengan kandungan kitin sebesar $20-30 \%$ pada ikan laut (Kumari, 2014).
Sisik ikan bandeng merupakan penyumbang terbesar limbah di Kota Tarakan karena ikan ini merupakan komoditi unggulan, selain udang, kepiting, dan rumput laut. Penggunaan biokoagulan berbasis kitosan dari limbah sisik ikan bandeng mempunyai beberapa keunggulan, yaitu sifatnya yang tidak beracun, terbarukan, mudah mengalami biodegradasi, bersifat polielektronik, dan mudah berinteraksi dengan zat-zat organik lainnya seperti protein (Renault et al. 2009; Sinardi et al. 2013; Li et al. 2016).

Berdasarkan pemaparan di atas, maka perlu dilakukan penelitian terkait Analisis perubahan kekeruhan terhadap limbah tahu dengan memanfaatkan biokoagulan berbasis kitosan dari limbah sisik ikan bandeng sehingga dapat menjadi solusi permasalahan lingkungan.

\section{METODOLOGI}

\section{Waktu dan tempat}

Penelitian ini dilaksanakan pada bulan Oktober 2019 - November 2019 di Laboratorium Nutrisi dan Laboratorium Kualitas Air Fakultas Perikanan dan Ilmu Kelautan Universitas Borneo Tarakan, Tarakan.

\begin{abstract}
Alat dan Bahan
Peralatan yang digunakan selama penelitian adalah turbidimeter, oven, dan peralatan gelas lainnya. Bahan utama adalah limbah sisik ikan bandeng yang diperoleh dari Pasar Gusher dan sampel limbah cair industri tahu di Kelurahan Karang Anyar. Bahan-bahan penunjang yaitu aquades, natrium hidroksida $(\mathrm{NaOH})$ 0,1 $\mathrm{N}$ dan 20\% (Merck), natrium klorida $(\mathrm{NaCl}) 1 \mathrm{~N}$ (Merck), dan asam asetat.
\end{abstract}




\section{Metode}

\section{Pengambilan Sampel}

Sampel limbah cair tahu diambil dari Industri rumah tangga yang berada di Karang Anyar, Kota Tarakan. Sampel yang diambil adalah sampel segar berupa limbah cair tahu sebelum dibuang ke Perairan.

Penambahan Biokoagulan Kitosan ke dalam Limbah Cair Tahu (Modifikasi metode Muruganandam et al. 2017; Ratnawulan 2018)

Sampel limbah tahu terlebih dahulu diukur turbiditasnya untuk mengetahui nilai kekeruhan awal. Selanjutnya, ditambahkan larutan kitosan masing-masing dengan rentang konsentrasi $10 \mathrm{ppm}, 20 \mathrm{ppm}, 30$ ppm pada limbah cair tahu tersebut. Pengadukan cepat (rapid mixing) dilakukan pada kecepatan $200 \mathrm{rpm}$ selama 1 menit, dilanjutkan dengan pengadukan lambat (slow mixing) pada kecepatan $50 \mathrm{rpm}$ selama 30 menit. Proses selanjutnya yaitu agitasi atau pengendapan selama 30 menit untuk memberikan kesempatan pada flok-flok yang terbentuk agar dapat mengendap. Langkah terakhir adalah dilakukan penyaringan. Hasil penyaringan kemudian dianalisis turbiditasnya menggunakan turbidimeter.

\section{Analisis Data}

Penelitian dilakukan sebanyak tiga kali ulangan dan dianalisis menggunakan analisis varians (One-Way ANOVA) untuk mengetahui perbedaan antara perlakuan dan kontrol. Signifikansi perbedaan rata-rata dengan tingkat kepercayaan $95 \%$ (kesalahan yang terjadi hanya 5\%). Program yang digunakan untuk menganalisis data tersebut menggunakan software SPSS 24.0.

\section{HASIL DAN PEMBAHASAN}

\section{Karakteristik Kitosan dari Limbah Sisik Ikan Bandeng}

Limbah sisik ikan bandeng yang telah dihancurkan, menyerupai serbuk. Serbuk yang digunakan dalam pembuatan kitosan sebesar 29,70 gram. Kitosan yang dibuat dari limbah sisik ikan bandeng melalui tiga tahapan, yaitu penghilangan protein (deproteinasi), penghilangan mineral (demineralisasi), dan penghilangan gugus asetil (deasetilasi).

Tahap deproteinasi adalah tahap penghilangan protein. Proses penghilangan protein dilakukan dengan ekstraksi menggunakan basa $\mathrm{NaOH}$ dan diperoleh serbuk 21,84 gram. Pada tahap ini ion $\mathrm{Na}^{+}$ akan mengikat protein sehingga terjadi pengentalan dengan munculnya sedikit gelembung dan perubahan warna (Dompeipen, 2017).

Tahap demineralisasi yaitu proses penghilangan mineral dari dalam kitin hasil deproteinasi menggunakan larutan $\mathrm{HCl}$ (Dompeipen, 2016). Mineral akan bereaksi dengan larutan asam membentuk garam terlarut sehingga akan terpisah pada saat pencucian dan penyaringan. Pada tahap ini, berat serbuk menyusut menjadi 11,47 gram.

Tahap terakhir, yaitu deasetilasi yang merupakan proses terbentuknya gugus amin. Proses deasetilasi menyebabkan gugus hidroksil dan amina yang terdapat pada kitosan mempunyai reaktivitas kimia yang tinggi (Adriana et al., 2001). Proses ini menggunakan larutan $\mathrm{NaOH} 20 \%$ sehingga terjadi reaksi adisi, yaitu gugus $\mathrm{OH}^{-}$dan gugus karbon pada kitin saling bereaksi menghasilkan zat antara yang akan mengalami reaksi eliminasi dengan gugus asetil pada kitin (Minda et al., 2010). Serbuk kitosan yang dihasilkan setelah melalui tiga tahapan ini berwarna putih dan tidak berbau.

\section{Kualitas Limbah Cair Industri Tahu}

Kualitas limbah cair tahu dilakukan dengan menganalisis tingkat kekeruhannya dan diperoleh nilai sebesar 847 NTU. Tingkat kekeruhan ini tergolong tinggi dan diasumsikan terjadi karena besarnya jumlah 
protein yang terdispersi dalam ukuran koloid. Protein ini berasal dari kedelai yang dipakai sebagai bahan baku pembuatan tahu. Sisa-sisa protein yang tidak terambil pada pembuatan tahu ini diduga menjadi penyebab kekeruhan pada limbah cair tahu (Hudiyanti, 1999).

\section{Pengaruh Penambahan Biokoagulan Kitosan Terhadap Turbiditas}

Turbiditas atau kekeruhan menunjukkan adanya zat tersuspensi di dalam air, yakni bahan organik dan anorganik sehingga dapat memepengaruhi proses kehidupan organisme di Perairan. Bahan anorganik dapat berupa pasir, pelapukan batuan, logam terlarut, dan lumpur, sedangkan bahan organik dapat berasal dari limbah industri atau domestik (Hendrawati et al., 2015). Nilai turbiditas limbah cair tahu yang telah diberi penambahan biokoagulan kitosan mengalami perubahan dari nilai turbiditas awalnya, yakni dari 847 NTU hingga 29,27 NTU. Perubahan nilai turbiditas ini dapat dilihat pada Gambar 1.

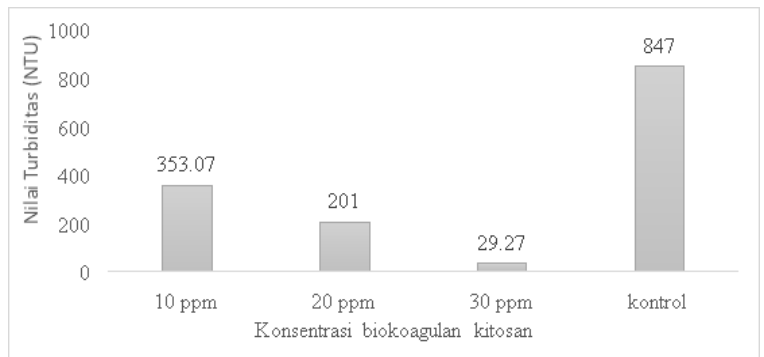

Gambar 1. Nilai turbiditas limbah tahu setelah diberi penambahan biokoagulan kitosan

Berdasarkan hasil penelitian diatas, penurunan nilai Turbiditas terjadi pada setiap kenaikan konsentrasi biokoagulan. Nilai turbiditas terendah yaitu pada biokoagulan kitosan dengan konsentrasi tinggi yaitu 30 ppm. Semakin tinggi konsentrasi yang ditambahkan ke dalam limbah cair tahu, maka nilai turbiditasnya semakin menurun (Sukma et al, 2018). Penurunan ini terjadi karena kitosan yang dipakai sebagai biokoagulan bersifat multi polimer bio, artinya mempunyai muatan positif dan mengandung amina bebas sehingga dapat berikatan dengan muatan negatif, yakni ion mineral, lemak, dan protein (Al-Manhel et al, 2016). Penggunaan kitosan pada pengelolaan limbah di industri memang cukup baik. Kitosan mempunyai sifat sebagai pengkelat, reaktivitas tinggi, dan selektivitas terhadap polutan juga tinggi (Oktarina et al., 2017).

\section{KESIMPULAN DAN SARAN}

\section{Kesimpulan}

Penambahan biokoagulan kitosan pada limbah cair tahu memberikan perubahan terhadap nilai turbiditas. Nilai turbiditas pada konsentrasi 10 ppm yaitu 353, 07 NTU, pada 20 ppm yaitu 201 NTU, dan pada konsentrasi 30 ppm, yaitu 29,27 NTU. Nilai turbiditas limbah cair tahu yang paling rendah setelah penambahan biokoagulan kitosan yaitu pada konsentrasi 30 ppm. Penggunaan dosis biokoagulan kitosan yang semakin tinggi dapat memperbaiki kualitas limbah cair tahu sebelum dibuang ke perairan.

\section{Saran}

Saran untuk penelitian selanjutnya adalah perlu dilakukan analisis $\mathrm{pH}$, Biochemical oxygen demand (BOD), Chemical oxygen demand (COD), dan Total suspended solid (TSS) untuk mengetahui tingkat keberhasilan penggunaan biokoagulan berbasis kitosan dalam memperbaiki kualitas limbah cair tahu sebelum dibuang ke perairan.

\section{UCAPAN TERIMAKASIH}

Ucapan terimakasih ditujukan kepada DIPAUBT yang telah membiayai penelitian ini 
melalui hibah skeam Penelitian Dosen Pemula (PDP).

\section{DAFTAR PUSTAKA}

Adriana A., Mudjiajati, E. Selvy, \& V. Setijawati. 2001. Adsorbs Cr (IV) dengan Adsorben Kitosan. Kimia Lingkungan 3: 31-36.

Al-Manhel AJ, Al-Hilphy ARS, Niamah AK. 2018. Extraction of chitosan, characterisation and its use for water purification. Journal of the Saudi Society of Agricultural Sciences. 17(2): 186-190.

Dompeipen, E. J. 2017. Isolation and Identification of Chitin and Chitosan From Windu Shrimp (Penaeus monodon) With Infrared Spertroscopy. Majalah BIAM. 13(01): $31-41$.

Dompeipen, E.J, Marni K. dan Riardi P. D. 2016. Isolation of Chitin and Chitosan from Waste of Skin Shrimp. Majalah BIAM, 12 (01): 32-38.

Hendrawati, Sumarni S, Nurhasni. 2015. Penggunaan kitosan sebagai koagulan alami dalam perbaikan kualitas air danau. Jurnal Kimia VALENSI. 1(1): 1-11.

Hudiyanti D. 1999. Penggunaan PAC pada limbah cair industri tahu. Jurnal kimia sains dan aplikasi. 2(1):13-18.

Levina E. 2016. Biogas from tofu waste for combating fuel crisis and environmental damage in Indonesia. Apec Youth Scientist Jounal. 8(1):1621.
Li A, Lin R, Lin C, He B, Zheng T, Lu L, Cao Y. 2016. An environment-friendly and multi-functional absorbent from chitosan for organic pollutants and heavy metal ion. Carbohydrate Polymers. 148: 272-280.

Kumari, S. dan Rath, P., K. 2014. Extraction and Characterization of Chitin and Chitosan from (Labeo rohit) Fish Scales. Procedia Materials Science. 6:482- 489.

Minda, A., Efendi J., Syofyeni E., Lesi R.M. dan Novalina S. 2010. Pengaruh Konsentrasi $\mathrm{NaOH}$ dan $\mathrm{KOH}$ terhadap Derajat Deasetilasi Kitin dari Limbah Kulit Udang. Jurnal Eksakta $1(11)$.

Muruganandam L, Kumar MPS, Jena A, Gulla S, Godhwani B. 2017. Treatment of waste water by coagulation and flocculation using biomaterials. IOP Conf. Series: Materials Science and Engineering. 263: 1-11.

Oktarina E, Adrianto R, Setiawati I. 2017. Imobilisasi bakteri pada kitosanalginat dan kitin-alginat. Majalah Teknologi Agro Industri (TEGI). 9(2): 1-8

Ratnawulan A, Noor E, Suptijah P. 2018. Pemanfaatan Kitosan dalam Daur Ulang Air sebagai Aplikasi Teknik Produksi Bersih. Jurnal Pengolahan Hasil Perikanan Indonesia, 21(2):276-286.

Renault F, Sancey B, Badot PM, Crini G. $2009 . \quad$ Chitosan for coagulation/flocculation processes - 
An eco-friendly approach. European Polymer Journal. 45(2009): 13371348.

Sinardi, Soewondo P, Notodarmojo S. 2013. Pembuatan karakterisasi dan aplikasi kitosan dari cangkang kerang hijau (Mytulus viridis linneaus) sebagai koagulan penjernih air. Konferensi Nasional Teknik Sipil 7: 33:38.

Suharto. 2011. Limbah Kimia dalam Pencemaran Udara dan Air. Yogyakarta (ID): ANDI.

Sukma DH, Riani E, Pakpahan EN. 2018. Pemanfaatan kitosan sebagai adsorben sianida pada limbah pengolahan bijih emas. Jurnal pengolahan dan hasil perikanan Indonesia. 21(3):460-470.

Wardhani K, Widyastuti, Hadiwidodo M, Sudarno. 2014. Khitin cangkang rajungan (Portunus pelagicus) sebagai biokoagulan untuk penyisihan turbidity, TSS, BOD dan COD pada pengolahan air limbah farmasi PT. Phapros Tbk, Semarang. Jurnal Teknik Lingkungan. 3(4): 1- 6. 